\title{
Perinuclear antineutrophil cytoplasmic antibodies in collagenous or lymphocytic colitis with or without celiac disease
}

\author{
Hugh James Freeman MD
}

\begin{abstract}
HJ Freeman. Perinuclear antineutrophil cytoplasmic antibodies in collagenous or lymphocytic colitis with or without celiac disease. Can J Gastroenterol 1997;11(5):417-420. Microscopic forms of colitis, including lymphocytic and collagenous colitis, have been observed in both those with and without celiac disease. Although perinuclear antineutrophil cytoplasmic antibodies ( $\mathrm{p}$ ANCA) occur in most patients with ulcerative colitis, investigations in microscopic, particularly lymphocytic, colitis are still needed. In this study atypical p-ANCA was evaluated in 55 patients, including 27 with celiac disease alone, 13 with celiac disease and concomitant lymphocytic colitis, and 15 with microscopic forms of colitis, including lymphocytic and collagenous colitis. Nine patients (16.3\%) had atypical p-ANCA, including six with celiac disease and three with a microscopic form of colitis alone. Although five of the six positive celiac disease patients had lymphocytic colitis, all three celiac disease patients with associated primary sclerosing cholangitis - a separate risk factor for a positive assay result - were serologically positive for atypical $\mathrm{p}$-ANCA. These results indicate for the first time that this serological marker may occur in histologically defined celiac disease with or without concomitant lymphocytic colitis. Furthermore, these results suggest that the pathogenesis of ulcerative colitis differs from that of lymphocytic colitis and further emphasizes the heterogeneous nature of these newly recognized types of colonic inflammatory mucosal disorders.
\end{abstract}

Key Words: Antineutrophil antibodies ( $p$-ANCA), Celiac disease, Collagenous colitis, Inflammatory bowel disease, Lymphocytic colitis, Ulcerative colitis

\begin{abstract}
Anticorps cytoplasmiques antineutrophiles périnucléaires dans la colite collagénique ou lymphocytaire avec ou sans maladie coliaque

RÉSUMÉ : Des formes microscopiques de colite, y compris la colite lymphocytaire et collagénique ont été observées chez les sujets atteints ou non de maladie coeliaque. Bien que les anticorps cytoplasmiques antineutrophiles périnucléaires ( $\mathrm{p}$-ANCA) s'observent chez la plupart des patients souffrant de colite ulcéreuse, il faut poursuivre la recherche sur la colite microscopique et particulièrement, lymphocytaire. Dans le cadre de cette étude, le dosage de p-ANCA atypiques a été effectué chez 55 patients, dont 27 atteints de maladie coliaque seule, 13 atteints de maladie coliaque et de colite lymphocytaire concomitante et 15 atteints de la colite microscopique, y compris de colite lymphocytaire et collagénique. Neuf patients $(16,3 \%)$ présentaient des p-ANCA atypiques, y compris six atteints de maladie coliaque et trois souffrant de la forme microscopique de colite seule. Bien que cinq des patients atteints de maladie coliaque positifs aient présenté une colite lymphocytaire, les trois patients atteints de maladie cœliaque associée à une cholangite sclérosante primaire, facteur de risque indépendant de résultats positifs au dosage, étaient séro-positifs à l'égard des p-ANCA atypiques. Ces résultats donnent à penser pour la première fois que ce marqueur sérologique puisse être présent dans la maladie cœliaque histologiquement définie, avec ou sans colite lymphocytaire concomitante. De plus, ces résultats suggèrent que la pathogenèse de la colite ulcéreuse diffère de celle de la colite lymphocytaire et souligne la nature hétérogène de ces troubles inflammatoires de la muqueuse du côlon de découverte récente.
\end{abstract}

This material previously appeared, in part, in abstract form (Gastroenterology 1996;110:A325,A909) and as a presentation at the

7th International Symposium on Celiac Disease, September 5 to 7, 1996, Helsinki, Finland

Departments of Medicine (Gastroenterology), University of British Columbia, Vancouver, British Columbia

Correspondence and reprints: Dr Hugh Freeman, ACU F-137, Gastroenterology, University Hospital, 2211 Wesbrook Mall, Vancouver,

British Columbia V6T 1W5. Telephone 604-822-7216, fax 604-822-7236

Received for publication October 2, 1996. Accepted January 6, 1997 
$\mathrm{I}_{\mathrm{c} m}^{\mathrm{n}}$ 1980 'microscopic colitis' was coined to describe a chronic mucosal inflammatory process in the colon of patients with diarrhea (1). Later, histopathological descriptions (2-5) noted a predominance of intra-epithelial lymphocytes in the inflammatory infiltrate; as a result the term 'lymphocytic colitis' emerged. Although this form of colitis is a distinctive entity in patients with diarrhea, it shares some clinical and histopathological features with another form of microscopic colitis: collagenous colitis (4-8). Most intra-epithelial lymphocytes in both of these microscopic types of colitis stain with a T cell marker (eg, MT-1) (9).

Interestingly, both lymphocytic and collagenous colitis have been recognized in patients with celiac disease (9-13). Indeed, in our initially reported studies (9), lymphocytic colitis was recognized in 12 of 39 celiac disease patients (31\%). Later, in an evaluation of 30 elderly celiac disease patients, lymphocytic colitis was recorded in 13 (43\%) (14). Similar findings have been reported in gastric epithelium from patients with celiac disease (15) and recently in the bile duct epithelium from a patient with celiac disease and sclerosing cholangitis (16). Moreover, pathological studies by other investigators have reported that up to $40 \%$ of patients with collagenous colitis also have celiac disease (17).

While these newly recognized forms of microscopic colitis, along with ulcerative colitis, may represent similar mucosal immunopathological processes, their precise relationship is unknown. The pathophysiological and possible diagnostic roles of serological markers in both ulcerative colitis and Crohn's disease have recently been explored. In a prospective study of Canadian patients with inflammatory bowel disease, for example, detection of atypical perinuclear antineutrophil cytoplasmic antibodies ( $\mathrm{p}$-ANCA) was reported in the majority of patients with ulcerative colitis, but only in a minority with Crohn's disease (18). To determine further whether this serological marker is also present in microscopic colitis, this investigation evaluated all recently diagnosed patients with lymphocytic or collagenous colitis with or without associated celiac disease.

\section{PATIENTS AND METHODS}

Patient groups: All patients in this investigation had histopathological features of celiac disease and/or microscopic types of colitis (ie, lymphocytic and collagenous colitis) as described earlier $(8,9)$. All patients with celiac disease had colonoscopic biopsies to determine whether lymphocytic or collagenous colitis was present. Conversely, all patients with lymphocytic or collagenous colitis had a small intestinal biopsy to determine whether the histopathological features of occult untreated celiac disease were present.

Results of the 55 patients were evaluated on the basis of histopathological diagnosis. Table 1 lists the results of 40 patients with celiac disease, including 13 patients with celiac disease and microscopic (ie, specifically lymphocytic) colitis, and 27 patients with celiac disease and no colitis. Results of 28 patients with microscopic colitis (ie, lymphocytic or collagenous colitis) are shown in Table 2, including the same 13 patients with celiac disease and 15 patients with no celiac
TABLE 1

Patients with celiac disease

\begin{tabular}{|c|c|c|c|c|}
\hline Patient & Age/sex & p-ANCA & LC & Other \\
\hline 1 & $55 / \mathrm{M}$ & - & LC & Small bowel cancer \\
\hline 2 & $43 / \mathrm{M}$ & - & LC & \\
\hline 3 & $71 / F$ & - & No colitis & T cell lymphoma \\
\hline 4 & $40 / \mathrm{M}$ & + & LC & \\
\hline 5 & $27 / F$ & - & No colitis & \\
\hline 6 & $50 / F$ & + & LC & PSC \\
\hline 7 & $47 / F$ & - & No colitis & \\
\hline 8 & $44 / F$ & - & No colitis & \\
\hline 9 & $42 / F$ & - & No colitis & Duodenal stricture \\
\hline 10 & $65 / F$ & - & LC & \\
\hline 11 & $84 / M$ & - & No colitis & T cell lymphoma \\
\hline 12 & $41 / F$ & - & No colitis & PBC \\
\hline 13 & $32 / F$ & - & LC & \\
\hline 14 & 21/M & - & No colitis & \\
\hline 15 & $42 / F$ & - & No colitis & \\
\hline 16 & $60 / F$ & - & No colitis & \\
\hline 17 & $60 / \mathrm{M}$ & + & LC & $\begin{array}{l}\text { T cell lymphoma, } \\
\text { PSC, DH }\end{array}$ \\
\hline 18 & $15 / F$ & - & LC & \\
\hline 19 & $52 / M$ & + & No colitis & \\
\hline 20 & $24 / F$ & - & No colitis & $\mathrm{DH}$ \\
\hline 21 & $52 / M$ & - & No colitis & \\
\hline 22 & $35 / F$ & - & No colitis & \\
\hline 23 & 78/M & + & LC & PSC \\
\hline 24 & $36 / F$ & + & LC & \\
\hline 25 & $62 / F$ & - & No colitis & T cell lymphoma \\
\hline 26 & $49 / F$ & - & No colitis & B cell lymphoma \\
\hline 27 & $23 / F$ & - & No colitis & \\
\hline 28 & $38 / F$ & - & No colitis & \\
\hline 29 & $61 / F$ & - & No colitis & \\
\hline 30 & $31 / F$ & - & LC & \\
\hline 31 & $17 / F$ & - & LC & \\
\hline 32 & $62 / F$ & - & No colitis & $\begin{array}{l}\text { Pancreatic } \\
\text { insufficiency }\end{array}$ \\
\hline 33 & $83 / F$ & - & No colitis & \\
\hline 34 & $60 / \mathrm{M}$ & - & No colitis & \\
\hline 35 & $29 / F$ & - & No colitis & \\
\hline 36 & $75 / F$ & - & No colitis & \\
\hline 37 & $41 / F$ & - & No colitis & \\
\hline 38 & $41 / F$ & - & No colitis & \\
\hline 39 & $37 / F$ & - & LC & $\mathrm{DH}$ \\
\hline 40 & $65 / F$ & - & No colitis & \\
\hline
\end{tabular}

DH Dermatitis herpetiformis; F Female; LC Lymphocytic colitis; $M$ Male; $p$-ANCA Perinuclear antineutrophil cytoplasmic antibodies; PBC Primary biliary cirrhosis; PSC Primary sclerosing cholangitis

disease. Two patients from this latter group (with microscopic colitis but no celiac disease) were also administered high gluten diets to exclude latent celiac disease; these studies were previously reported (19).

All serological samples for this prospective study were collected in a consecutive fashion with no exclusions or re- 
fusals; all samples were from out-patients rather than hospitalized patients.

Control groups: This study was completed using the same laboratory protocols previously reported by the author and co-workers (18). In that prior study, 194 of 500 consecutively studied patients with inflammatory bowel disease were positive for atypical $\mathrm{p}$-ANCA versus none of 32 consecutive controls with either no detectable disease (infectious or ischemic colitis). In inflammatory bowel disease patients, $66.3 \%$ of 247 ulcerative colitis patients and $11.8 \%$ of 253 Crohn's disease patients were positive for atypical p-ANCA.

Laboratory studies: For each patient blood samples were collected into vacutainer glass tubes (Becton Dickinson, New Jersey) for hematological studies (hemoglobin, white blood cell count, platelet count), an erythrocyte sedimentation rate test, liver chemistry tests (aspartate aminotransferase, alanine aminotransferase and alkaline phosphatase), and serum protein, including serum albumin, and serum iron studies.

Blood samples were also collected into vacutainer glass tubes, allowed to clot at room temperature and used for detection of ANCA with ANCA indirect immunofluorescence; if atypical p-ANCA was detected, ANCA ELISA was done. As reported elsewhere with coded sera examined in a blinded fashion (18), excellent agreement was present between immunofluorescence and ELISA results.

ANCA immunofluorescence: ANCA immunofluorescence was performed using a standardized indirect fluorescence antibody detection method with a proprietary kit purchased from a commercial supplier (Inova Diagnostics Inc, California). Laboratory methods used were previously detailed (18). ELISA assays: ANCA ELISA assays were performed using a standardized method (18) with commercial kits (QuantaLite MPO or PR3 ELISA, Inova Diagnostics Inc). The test kits use microtitration strips containing wells coated with proteinase-3 or myeloperoxidase. The laboratory methods used have been detailed (18).

\section{RESULTS}

Nine of the 55 patients $(16.3 \%)$ were positive for atypical pANCA, including six of $40(15 \%)$ celiac disease patients with or without associated lymphocytic colitis - and three of 15 (20\%) with microscopic colitis, either lymphocytic or collagenous colitis, but with no histological evidence for celiac disease. Thus, for both patient groups, the percentage of positive sera in the present investigation approximated the percentage of positive sera previously defined in patients with Crohn's disease rather than in ulcerative colitis (18).

Table 1 shows findings from 40 celiac disease patients. There were 30 females and 10 males, reflecting the previously reported overall female predominance in celiac disease (14). Average age of initial diagnosis of celiac disease was earlier for females than for males, ie, 44.8 years compared with 54.5 years, consistent with previous studies (14). Of the six patients with celiac disease (including two females and four males, average age 52.7 years) positive for atypical p-ANCA, five had a microscopic form of colitis, specifically lymphocytic colitis, including all three celiac
TABLE 2

Patients with microscopic colitis

\begin{tabular}{|c|c|c|c|c|c|}
\hline Patient & $\begin{array}{l}\text { Age/ } \\
\text { sex }\end{array}$ & p-ANCA & $\begin{array}{l}\text { LC or } \\
\text { CC }\end{array}$ & $\begin{array}{c}\text { Celiac } \\
\text { disease }\end{array}$ & Other \\
\hline 1 & $56 / F$ & - & LC & None & \\
\hline 2 & $55 / \mathrm{M}$ & - & LC & Present & Small bowel cancer \\
\hline 3 & $38 / F$ & - & $\mathrm{CC}$ & None & \\
\hline 4 & $43 / \mathrm{M}$ & - & LC & Present & \\
\hline 5 & $40 / \mathrm{M}$ & + & LC & Present & \\
\hline 6 & $67 / \mathrm{M}$ & - & LC & None & \\
\hline 7 & $64 / F$ & - & LC & None & \\
\hline 8 & $56 / F$ & - & LC & None & \\
\hline 9 & $56 / F$ & - & $\mathrm{CC}$ & None & Spleen atrophy \\
\hline 10 & $50 / F$ & + & LC & Present & PSC \\
\hline 11 & $55 / F$ & - & $\mathrm{CC}$ & None & Giant cell arteritis \\
\hline 12 & $52 / \mathrm{M}$ & - & $\mathrm{CC}$ & None & \\
\hline 13 & $67 / F$ & - & LC & None & \\
\hline 14 & $82 / F$ & - & LC & None & \\
\hline 15 & $65 / F$ & - & LC & Present & \\
\hline 16 & $84 / \mathrm{M}$ & - & LC & Present & T cell lymphoma \\
\hline 17 & $74 / F$ & + & $\mathrm{CC}$ & None & \\
\hline 18 & $32 / F$ & - & LC & Present & \\
\hline 19 & $60 / M$ & + & LC & Present & $\begin{array}{c}\text { T cell lymphoma, } \\
\text { DH, PSC }\end{array}$ \\
\hline 20 & $15 / F$ & - & LC & Present & \\
\hline 21 & $43 / F$ & + & LC & None & \\
\hline 22 & $42 / F$ & - & LC & None & \\
\hline 23 & $78 / \mathrm{M}$ & + & LC & Present & PSC \\
\hline 24 & $56 / F$ & - & LC & None & \\
\hline 25 & $36 / F$ & + & LC & Present & \\
\hline 26 & $31 / F$ & - & LC & Present & \\
\hline 27 & $17 / F$ & - & LC & Present & \\
\hline 28 & $36 / F$ & + & LC & None & \\
\hline
\end{tabular}

CC Collagenous colitis; DH Dermatitis herpetiformis; F Female; LC Lymphocytic colitis; M Male; $p$-ANCA Perinuclear antineutrophil cytoplasmic antibodies; PSC Primary sclerosing cholangitis

disease patients with primary sclerosing cholangitis. Primary sclerosing cholangitis appears to be an independent risk factor associated with atypical p-ANCA (20). Three of the 37 remaining celiac disease patients $(8.1 \%)$ were positive for this serological marker. Other disorders or complications of celiac disease, such as lymphoma, were not associated with positive atypical $\mathrm{p}$-ANCA results.

Table 2 lists results from 28 patients with a microscopic form of colitis, either lymphocytic or collagenous colitis. Thirteen had a concomitant diagnosis of celiac disease and 15 had no detectable celiac disease using endoscopic small intestinal biopsies. Two of the 15 patients had also been treated with a high gluten diet but latent celiac disease was not detected (19). Overall, eight of 28 patients (28.6\%) with microscopic colitis were positive for atypical p-ANCA.

Five of 13 patients (38.5\%) with concomitant celiac disease were positive (including three patients with associated 
primary sclerosing cholangitis). Three of 15 patients (20\%) with no concomitant celiac disease were positive; in two of these patients with microscopic colitis and no celiac disease, there was a positive family history of documented ulcerative colitis, and one patient was positive for atypical p-ANCA. There was no familial history of inflammatory bowel disease in the celiac disease patients.

\section{DISCUSSION}

This study demonstrated that the previously recorded detection rate of atypical p-ANCA of almost 70\% - in the majority of patients from our centre with ulcerative colitis (18) was not observed in this prospective evaluation of celiac disease patients. Indeed, if celiac disease patients with primary sclerosing cholangitis were excluded from the analysis, only three of the remaining 37 patients $(8.1 \%)$ were positive for this serological marker, approximating the percentage of patients with Crohn's disease (ie, about 10\%) in our centre (18). The present results also appear to confirm the findings of Bansi et al (21), the only earlier study reporting results in celiac disease patients. In their report, however, the serological marker p-ANCA could not be detected in any of the 17 celiac disease or 10 dermatitis herpetiformis patients.

The present study also confirms that patients with primary sclerosing cholangitis are often positive for this marker (20); however, in the present investigation observations were extended to patients with primary sclerosing cholangitis and concomitant celiac disease.

\section{REFERENCES}

1. Read NW, Krejs GJ, Read MG, Santa Ana CA, Morawski SG, Fordtran JS. Chronic diarrhea of unknown origin. Gastroenterology 1980;78:264-71.

2. Kingham JG, Levinson DA, Ball JA, Dawson AM. Microscopic colitis - a cause of chronic watery diarrhea. BMJ 1982;285:1601-4.

3. Bo-Linn GW, Vendrell DD, Lee E, Fordtran JS. An evaluation of the significance of microscopic colitis in patients with chronic diarrhea. J Clin Invest 1985;75:1559-69.

4. Lazenby AJ, Yardley JH, Giardiello FM, Jessurun J, Bayless TM. Lymphocytic (microscopic) colitis: a comparative histopathologic study with particular reference to collagenous colitis. Hum Pathol 1989;20:18-28.

5. Yardley JH, Lazenby AJ, Giardiello FM, Bayless TM. Collagenous, "microscopic", lymphocytic, and other gentler and more subtle forms of colitis. Hum Pathol 1990;21:1089-91.

6. Freeman HJ, Weinstein WM, Shnitka TK, Wensel R, Sartor V. Watery diarrhea syndrome associated with a lesion of the colonic basement membrane-lamina propria interface. Ann R Coll Phys Surg Can 1976;9:45.

7. Lindstrom CG. Collagenous colitis with watery diarrhea - a new entity. Path Europ 1976;11:87-9.

8. Freeman HJ. Collagenous inflammatory mucosal diseases of the gastrointestinal tract. Can J Gastroenterol 1990;4:196-200.

9. Wolber R, Owen D, Freeman H. Colonic lymphocytosis in patients with celiac sprue. Hum Pathol 1990;21:1092-6.

10. Hamilton I, Sanders S, Hopwood D, Bouchier IAD. Collagenous colitis associated with small intestinal villous atrophy. Gut 1986;27:1394-8.

11. Breen EG, Coughlan G, Connolly CE, Stevens FM, McCarthy CF. Coeliac proctitis. Scand J Gastroenterol 1987;22:471-7.

12. Cadiot G, Flourie B, Galian A, Lavergne A, Modigliani R. Coeliac disease and collagenous colitis. A fortuitious association. Presse Med 1990;19:1621-2.
Although this was the first study to evaluate patients with lymphocytic colitis for this serological marker (atypical pANCA) some prior studies have evaluated patients with collagenous colitis. Duerr and colleagues (22) initially recorded that five of $35(14 \%)$ patients with collagenous colitis were positive for atypical $\mathrm{p}$-ANCA, although diagnostic criteria for collagenous colitis and associated intestinal disorders, such as celiac disease, were not detailed. Similarly, Bohr et al (23) observed that four of $38(11 \%)$ with collagenous colitis were positive for atypical $\mathrm{p}$-ANCA. Although the frequency of concomitant celiac disease was not provided, $3 \%$ to $5 \%$ of sera from these collagenous colitis patients also had antibodies to endomysium and gliadin. Their results indirectly suggest - as do ours - that microscopic forms of colitis, even if associated with celiac disease, differ in immunopathogenesis from ulcerative colitis, a disorder with a very high detection rate of $\mathrm{p}$-ANCA. Identification of the antigen(s) to which these autoantibodies are directed may facilitate understanding of the underlying immune response, not only in ulcerative colitis, but also in other forms of inflammatory bowel disease, including these microscopic forms of colitis.

This investigation also serves to emphasize further that microscopic forms of colitis represent a heterogeneous group of colonic inflammatory mucosal disorders. In some patients, celiac disease coexists, whereas in others, no clear relationship to celiac disease is evident. Future studies, using novel serological markers, may aid in further definition of these emerging entities.

13. O’Mahony S, Nawroz IM, Ferguson A. Coeliac disease and collagenous colitis. Postgrad Med J 1990;66:238-41.

14. Freeman HJ. Clinical spectrum of biopsy-defined celiac disease in the elderly. Can J Gastroenterol 1995;9:42-6.

15. Wolber R, Owen D, DelBuono L, Appelman H, Freeman HJ. Lymphocytic gastritis in patients with celiac sprue or sprue-like intestinal disease. Gastroenterology 1990;98:310-5.

16. Freeman HJ, Kwan WCP. Occult celiac disease associated with lymphocytic sclerosing cholangitis. Can J Gastroenterol 1994;8:249-52.

17. Armes J, Gee DC, Macrae FA, Schroeder W, Bhathal PS. Collagenous colitis: jejunal and colorectal pathology. J Clin Pathol 1992;45:784-7.

18. Freeman HJ, Roeck B, Devine D, Carter C. Prospective evaluation of neutrophil auto-antibodies in 500 consecutive patients with inflammatory bowel disease. Can J Gastroenterol 1997;11:203-7.

19. Freeman HJ. Failure of added dietary gluten to induce small intestinal histopathological changes in patients with watery diarrhea and lymphocytic colitis. Can J Gastroenterol 1996;10:436-9.

20. Duerr RH, Targan SR, Landers CJ, et al. Neutrophil cytoplasmic autoantibodies: a link between primary sclerosing cholangitis and ulcerative colitis. Gastroenterology 1991;100:1385-91.

21. Bansi DS, Fleming KA, Chapman RW. Importance of antineutrophil cytoplasmic antibodies in primary sclerosing cholangitis and ulcerative colitis: prevalence, titre and IgG subclass. Gut 1996;38:384-9.

22. Duerr RH, Targan SR, Landers CJ, Sutherland LR, Shanahan F. Anti-neutrophil cytoplasmic antibodies in ulcerative colitis. Comparison with other colitides and diarrheal illnesses. Gastroenterology 1991;100:1590-6.

23. Bohr J, Tysk C, Yang P, Danielsson D, Jarnerot G. Autoantibodies and immunoglobulins in collagenous colitis. Gut 1996;39:73-6. 


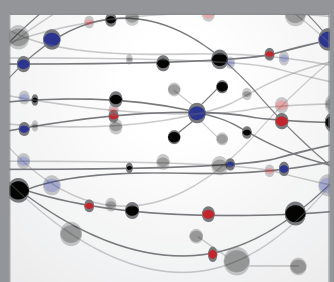

The Scientific World Journal
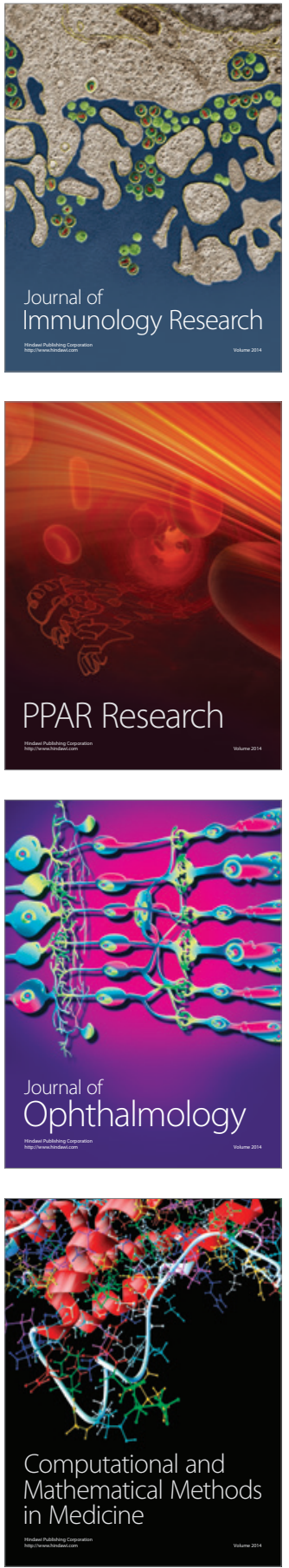

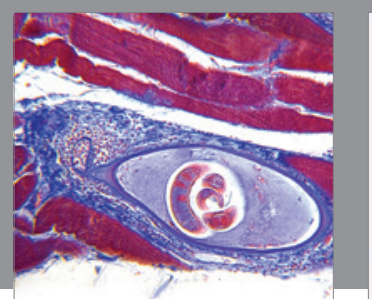

Gastroenterology Research and Practice

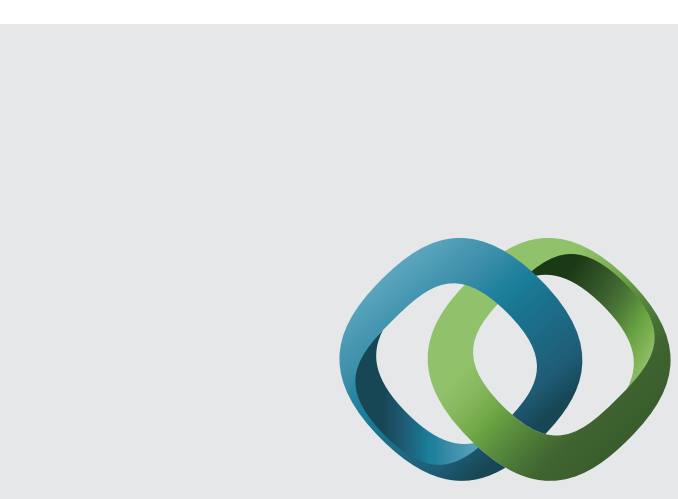

\section{Hindawi}

Submit your manuscripts at

http://www.hindawi.com
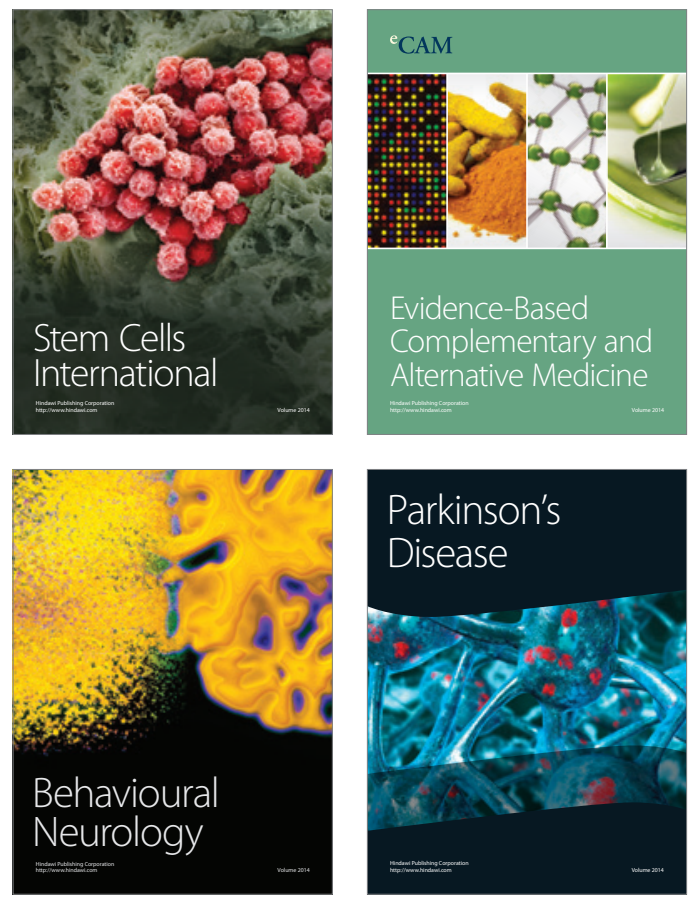
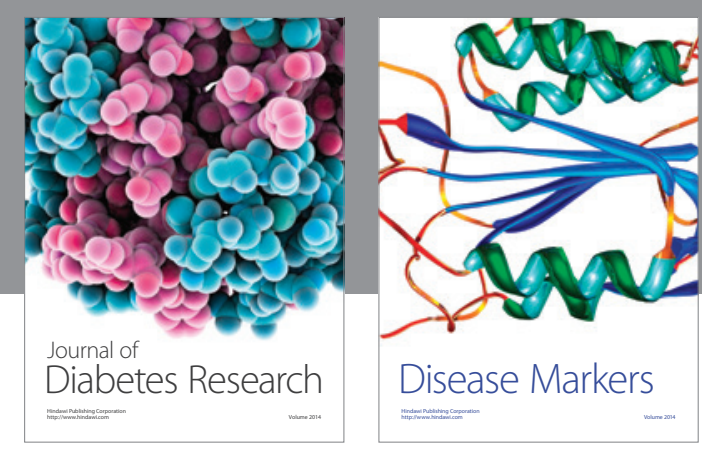

Disease Markers
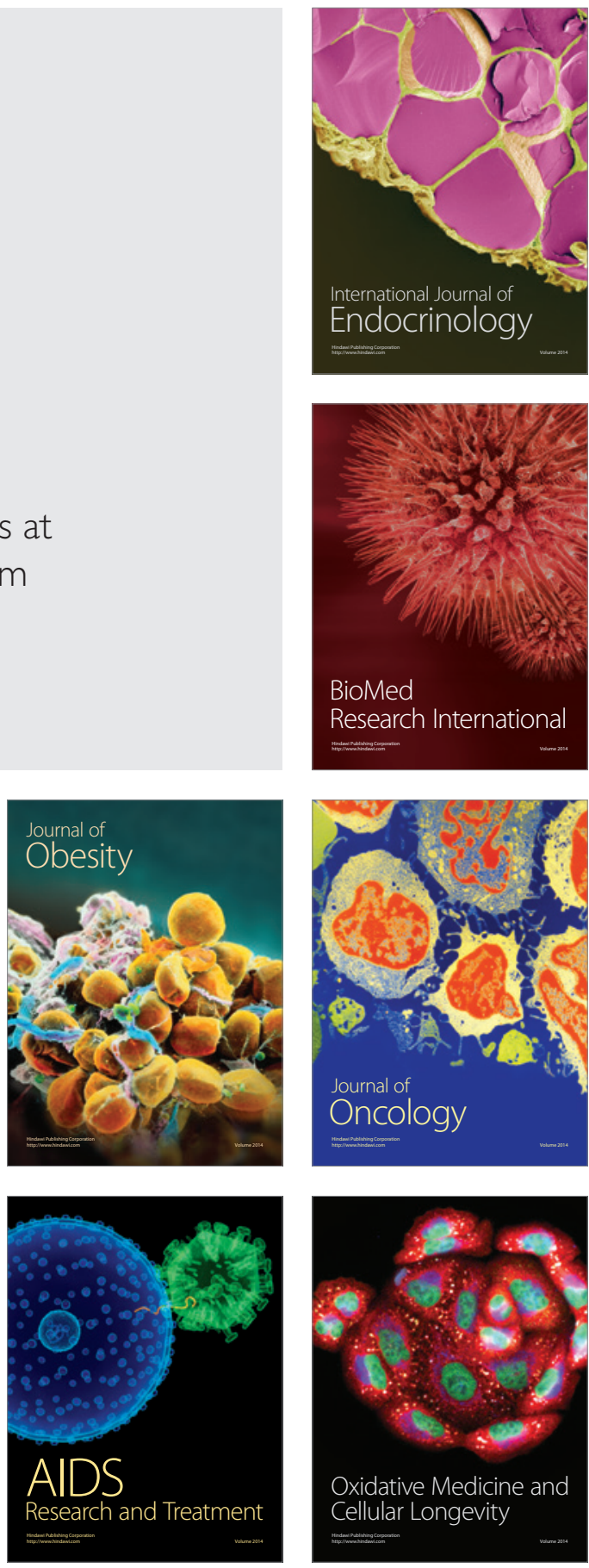